\title{
ARTHROPOD DIVERSITY IN RICE NURSERIES IN NORTH-EASTERN ZONE OF TAMIL NADU
}

\author{
*J. Diraviam, *M. Selvanayagam and ${ }^{* *}$ S. Ignacimuthu
}

\begin{abstract}
Agricultural systems are often considered by ecologists as disturbed, depouperate, and evolutionarily recent. But, tropical rice agro-ecosystem is one exception due to its ecological complexity resulted by the long ecological history and wide geographical distribution. Rice nursery is very similar to natural grassland and offers a wide scope for studying the biodiversity due to the presence of diverse arthropod fauna.

A survey was conducted in five rice nursery fields in the same period in three villages of two districts of the northeastern zone of Tamil Nadu: Budur, Kavarapettai and Narasingapuram of Tiruvallur district, and Kovur and Malaiyambakkam of Kancheepuram district during Somavari season, 2003 (April to August). The rice cultivar was uniformly ADT 43, a short duration variety. No chemical pesticide was applied in the nursery fields and the seedlings were of uniform age. Fifty double sweep net samples were token to study the orthropod diversity. The specimens sorted out
\end{abstract}

* Entomological Research Centre, Loyola College, Chennai 600 034, T.N.

* Director of Entomological Research Centre, Loyolo College, Chennai 600 034, T.N. Former Vice Chancellor of Madras University. 
were grouped into three guilds, viz., pests, entomophages and neufrals, and their relative abundance was worked out.

The overall observations revealed that a wide range of arthropod fauna were present in the rice nursery fields. The neutrals were the most dominant guild in four out of five locations. Their relative abundance ranged from 30.22 to $67.13 \%$. This guild was followed by the pests, which ranged from 17.52 to $48.58 \%$. The abundance of entomophages ranged from 13.32 to $24.36 \%$. Among the locations, the maximum relative abundance of pest and entomophage guilds was obsenved in Narasingapuram. The maximum relative abundance of neutrals was observed in Budur.

The green leaf hopper, whiteflies, white-backed planthopper, grasshoppers and thrips were the major pests. The predominant entomophages were the spiders, parasitic hymenoptera and ground beetles. Dipteran flies and hydrophilids were the predominant neutrals obsenved. If may be concluded that rice nursery field supports a broad range of arthropods. The neutrals help in the build up of carnivores (entomophages), which ultimately check the pest populations.

\section{Introduction}

Rice is the staple food for over $65 \%$ of the Indian population. It is grown in the country in an area of about 43 million hectares. Rice cultivation is thought to have originated in northeast Thailand nearly nine thousand years ago (Bray, 1986). Its long ecological history, together with high adaptation for extensive geographic distribution, and the ideal warm and wet climatic conditions, has resulted in an agricultural ecosystem unrivaled by any other in the world in terms of ecological complexity.

'Biological diversity (= Biodiversity) is the full range of variety and variability within and among living organisms, their associations, and habitat-oriented ecological complexes. The term encompasses ecosystem, species, and landscape as well as intra-specific (genetic) levels of diversity' (Fielder and Jain, 1992). The desirability of measuring biodiversity has been stated by many authors, principally on the grounds that it enables the concept of biodiversity to be subjected to rigorous empirical enquiry. The measurement of diversity is complex. Broadly, there are two kinds of measures, those, which simply count entities and those, which additionally attempt to incorporate some elements of their difference.

Much of the complexity of an ecosystem resides in its biodiversity and it is precisely this biodiversity that is most negatively affected by input-driven agriculture. When 
little or no insecticide is used, tropical irrigated rice fields possess a rich arthropod community including many different kinds of natural enemies and in these circumstances, their species richness and abundance may sometimes be greater than those of pests (Heong et al., 1991). In a four-year study on transplanted rice crop from Java, Settle et al. (1996) observed over 765 species of arthropods, of which $40 \%$ were predators, $24.4 \%$ parasitoids, $16.6 \%$ herbivores, and $19 \%$ detritivores and plankton feeders.

In India, Beevi et al. (2003) studied the relative abundance of rice arthropods in six villages of two panchayats of Kerala. They reported that entomophages viz., predators and parasitoids were the most dominant group followed by phytophages and then the detritivores in transplanted rice. Nursery field offers a conducive environment for the survival of arthropods due to the ideal micro-climate. The present study was taken up to assess the diversity of arthropods in five rice nurseries in two districts of Tamil Nadu state.

\section{Materials and Methods}

The survey was conducted in five rice nursery fields in the same period in two districts of the northeastern zone of Tamil Nadu: Budur, Kavarapettai and Narasingapuram of Tiruvallur district and Kovur and Malaiyambakkam of Kancheepuram district during Sornavari season, 2003 (April to August). The rice cultivar was uniformly ADT 43, a short duration variety. No chemical pesticide was applied in the nursery fields and the seedlings were of uniform age. Fifty double sweep net samples were taken to study the arthropod diversity. The sweep net collections were brought to the laboratory and they were sorted out and counted using a stereomicroscope. All the arthropods obtained in the samples were grouped based on their taxonomic order, genera and identified up to species level, wherever possible. The sorted out specimens were further grouped into three guilds, viz., pests, entomophages and neutrals, and their relative abundance was worked out.

\section{Results and Discussion}

The overall observations revealed that a wide range of arthropod fauna were present in the rice nursery fields (Table 1,2). The relative abundance of the three guilds: pests, entomophages and neutrals are given in Table 3 . The neutrals were the most dominant guild in four out of five locations. Their relative abundance ranged from 30.22 to $67.13 \%$. Similarly, Settle ef al. (1996) observed the detritivores to be the dominant guild during the 30 to 50 days after transplanting in Java. 
Table 1. Population of pests on rice nursery fields in five locations

\begin{tabular}{|c|c|c|c|c|c|}
\hline \multirow[t]{2}{*}{ Taxa } & \multicolumn{5}{|c|}{ Population / 50 double net sweeps } \\
\hline & Budur & $\begin{array}{c}\text { Narasinga- } \\
\text { puram }\end{array}$ & Kovur & $\begin{array}{c}\text { Malai- } \\
\text { yambakkam }\end{array}$ & Kavarapettai \\
\hline $\begin{array}{l}\text { Brown planthopper, } \\
\text { Nilaparvata lugens (Stal.) }\end{array}$ & 10 & 1 & 1 & 1 & 7 \\
\hline $\begin{array}{l}\text { White-backed planthopper, } \\
\text { Sogatella furcifera (Horv.) }\end{array}$ & 75 & 6 & 3 & 10 & 1 \\
\hline $\begin{array}{l}\text { Green leaf hopper, } \\
\text { Nephotettix virescens } \\
\text { (Distant) }\end{array}$ & 62 & 194 & 17 & 101 & 599 \\
\hline $\begin{array}{l}\text { Zigzag leaf hopper, } \\
\text { Deltocephalus dorsalis } \\
\text { (Motschulsky) }\end{array}$ & 9 & 6 & 1 & 1 & 13 \\
\hline $\begin{array}{l}\text { Blue leaf hopper, } \\
\text { Emposcnara indica }\end{array}$ & 0 & 5 & 4 & 48 & 46 \\
\hline $\begin{array}{l}\text { Other leaf hoppers } \\
\text { Whitefly, } \\
\text { Bemisia tabaci (Gennadius) }\end{array}$ & $\begin{array}{c}1 \\
121\end{array}$ & $\begin{array}{c}4 \\
72\end{array}$ & $\begin{array}{l}1 \\
3\end{array}$ & $\begin{array}{c}0 \\
153\end{array}$ & $\begin{array}{c}6 \\
77\end{array}$ \\
\hline $\begin{array}{l}\text { Thrips, } \\
\text { Stenchaetothrips biformis } \\
\text { (Bagnall) }\end{array}$ & 54 & 113 & 10 & 89 & 53 \\
\hline $\begin{array}{l}\text { Pyralidae } \\
\text { Skipper, } \\
\text { Pelopidas mathias F. }\end{array}$ & $\begin{array}{l}21 \\
0\end{array}$ & $\begin{array}{l}5 \\
4\end{array}$ & $\begin{array}{l}1 \\
1\end{array}$ & $\begin{array}{l}4 \\
0\end{array}$ & $\begin{array}{l}2 \\
0\end{array}$ \\
\hline $\begin{array}{l}\text { Flea beetles } \\
\text { Grasshopper, } \\
\text { Oxya spp. }\end{array}$ & $\begin{array}{l}0 \\
1\end{array}$ & $\begin{array}{c}0 \\
459\end{array}$ & $\begin{array}{c}1 \\
59\end{array}$ & $\begin{array}{c}1 \\
19\end{array}$ & $\begin{array}{c}1 \\
62\end{array}$ \\
\hline Others & 0 & 10 & 1 & 0 & 16 \\
\hline
\end{tabular}


Table 2. Population of entomophages and neutrals on rice nursery fields in five locations

\begin{tabular}{|c|c|c|c|c|c|}
\hline \multirow[t]{2}{*}{ Taxa } & \multicolumn{5}{|c|}{ Population / 50 double net sweeps } \\
\hline & Budur & $\begin{array}{l}\text { Narasinga- } \\
\text { puram }\end{array}$ & Kovur & $\begin{array}{c}\text { Malai- } \\
\text { yambakkam }\end{array}$ & Kavarapettai \\
\hline \multicolumn{6}{|l|}{ Predators } \\
\hline Spiders & 16 & 49 & 5 & 26 & 95 \\
\hline Damselflies & 12 & 3 & 14 & 1 & 1 \\
\hline $\begin{array}{l}\text { Ground beetle, } \\
\text { Ophionea indica (Thunberg) }\end{array}$ & 1 & 52 & 1 & 9 & 37 \\
\hline $\begin{array}{l}\text { Ladybird beetle, } \\
\text { Micraspis sp. }\end{array}$ & 2 & 16 & 3 & 6 & 54 \\
\hline $\begin{array}{l}\text { Mirid bug, } \\
\text { Cyrtorhinus lividipennis } \\
\text { Reuter }\end{array}$ & 6 & 23 & 2 & 1 & 7 \\
\hline Ants & 3 & 21 & 2 & 12 & 1 \\
\hline $\begin{array}{l}\text { Rove beetle, } \\
\text { Paederus fuscipes Curtis }\end{array}$ & 0 & 8 & 3 & 4 & 40 \\
\hline $\begin{array}{l}\text { Long horned grasshopper, } \\
\text { Conocephalus sp. }\end{array}$ & 0 & 16 & 0 & 0 & 0 \\
\hline Others & 0 & 4 & 2 & I & 3 \\
\hline \multicolumn{6}{|l|}{ Parasitoids } \\
\hline Hymenoptera & 267 & 188 & 37 & 97 & 361 \\
\hline Diptera & 3 & 0 & 0 & 0 & 0 \\
\hline \multicolumn{6}{|l|}{ Neutrals } \\
\hline Diptera & 1331 & 533 & 238 & 584 & 811 \\
\hline Hydrophilidae & 12 & 0 & 3 & 5 & 122 \\
\hline Other Coleoptera & 10 & 1 & 0 & 2 & 42 \\
\hline Others & 1 & 0 & 1 & 0 & 0 \\
\hline
\end{tabular}


Table 3. Relative abundance of pests, entomophages and neutrals in rice nursery fields in five locations (percentage):

\begin{tabular}{|l|c|c|c|c|c|}
\hline Category & Budur & $\begin{array}{c}\text { Narasinga- } \\
\text { puram }\end{array}$ & Kovur & $\begin{array}{c}\text { Malai- } \\
\text { yambakkam }\end{array}$ & Kavarapettai \\
\hline Pests & 17.52 & 48.58 & 24.64 & 36.33 & 35.89 \\
\hline Entomophages & & & & & \\
\hline Predators & 1.98 & 10.71 & 7.73 & 5.09 & 9.70 \\
\hline Parasitoids & 13.37 & 10.49 & 8.94 & 8.23 & 14.66 \\
\hline $\begin{array}{l}\text { Total } \\
\text { entomophages }\end{array}$ & 15.35 & 21.20 & 16.67 & 13.32 & 24.36 \\
\hline Neutrals & 67.13 & 30.22 & 58.69 & 50.34 & 39.75 \\
\hline
\end{tabular}

This neutrals guild was followed by the pests, which ranged from 17.52 to $48.58 \%$. However, in transplanted fields in Kerala, phytophages were the most dominant guild (Beevi ef al., 2003). The abundance of entomophages ranged from 13.32 to $24.36 \%$. Among the locations, the maximum relative abundance of pest and entomophage guilds was observed in Narasingapuram. The maximum relative abundance of neutrals was observed in Budur.

The green leaf hoppers were the most dominant taxa among the pests ranging from 17 to 599 per 50 sweeps in Kovur and Kavarapettai, respectively. This was followed by the whitefly, white-backed planthopper, grasshoppers and thrips. Beevi et al. (2003) also observed green leaf hoppers and thrips to be the major pests in transplanted fields. The predominant entomophages were the spiders, parasitic hymenoptera and ground beetles. The findings are in agreement with earlier study by Beevi et al. (2003). Dipteran flies and hydrophilids were the predominant neutrals observed. Though the study was made on the same variety and in the same period, there were some variations in the relative abundance among the guilds in the five locations. This is due to the fact that arthropod communities vary with environment and the management practices (Heong ef al., 1992). It may be concluded that rice nursery field supports a broad range of arthropods including herbivores, carnivores, neutrals and detritivores. The neutrals also help in the build up of carnivores: predators and parasitoids, which eventually keep the pest populations under check. 


\section{References}

1. Beevi, S. P., Meera, P. and Lyla, K. R. 2003. Diversity and relative abundance of pests and natural enemies in the rice ecosystem. In: Biological control of insect pests (eds.) S. Ignacimuthu and S. Jayaraj, Phoenix Pub. House Pvt. Ltd., New Delhi, pp 224-23i.

2. Bray, F. 1986. The rice economies. Blackwell, Oxford, England.

3. Fielder, P. L. and Jain, S. K. (ed.). 1992. Conservation biology: The theory and practice of nature conservation and management. Chapman and Hall, New York.

4. Heong, K. L., Aquino, G. B. and Barrion, A.T. 1991. Arthropod community structures of rice ecosystems in the Philippines. Bull. Entomol. Res. 81: 407-416.

5. Heong, K. L., Aquino, G. B. and Barrion, A.T. 1992. Population dynamics of plant and leaf hoppers and their natural enemies in rice ecosystems in the Philippines. Crop Prot. 11 : 371.379 .

6. Settle, W. H., Ariawan, H., Astuti, E. T., Cahyana, W., Hakim, A. L., Hindayana, D., Lestari, A. S., Pajarningsih and Sartanto. 1996. Managing tropical rice pests through conservation of generalist natural enemies and alternative prey; Ecology 77 1975-1988. 